Journal of Business \& Management

Volume 1, Issue 1 (2012), 29-39

ISSN 2291-1995 E-ISSN 2291-2002

Published by Science and Education Centre of North America

\title{
Expatriate Job Performance and Adjustment: Role of Individual and Organizational Factors
}

\author{
Muhammad Awais Bhatti ${ }^{1 *}$, Veera Pandiyan Kaliani Sundram² \& Hoe Chee Hee \\ ${ }^{1}$ School of Business Management, College of Business, Universiti Utara Malaysia, Kedah-Malaysia \\ ${ }^{2}$ University Technology MARA, Segamat, Johor, Malaysia \\ ${ }^{3}$ College of Business, Universiti Utara Malaysia, Kedah-Malaysia \\ *Correspondence: Dr. Muhammad Awais Bhatti, School of Business Management, College of \\ Business, Universiti Utara Malaysia, Sintok-Kedah, Malaysia. Tel: +60-13-4292297; Email: \\ awaisbhatti_786@yahoo.com
}

\begin{abstract}
The expatriate literature has highlighted many individual and organizational factors which effect expatriate job performance and adjustment but the role of some individual and organizational factors is still not clear and/or has been ignored by past researchers. For example, the role of direct and indirect support has not been well conceptualized in past studies. In addition, only a few studies have explained the importance of self-efficacy, cultural sensitivity and social networking in the related expatriate literature. Furthermore, the role of previous international experience has conflicting results in past research. The purpose of this paper is to provide a theoretical grounding and highlight the importance of those individual and organizational factors which have been ignored by past researchers. In this regard, researchers have reviewed journals/articles from different databases, books, and magazines. This paper proposes a comprehensive framework based on the gaps in the literature and suggests propositions. The proposed conceptual framework provides a theoretical grounding for individual and organizational factors that includes individual factors (self-efficacy, previous international experience, cultural sensitivity, and social network) and organizational factors (direct and indirect support). This paper suggests that expatriate adjustment (work, general, and interaction adjustment) mediates the relationship between individual factors (self-efficacy, previous international experience, cultural sensitivity, and social network), organizational factors (direct and indirect support), and expatriate job performance (rated by peer and supervisor). The proposed framework is developed based on past theoretical and empirical studies in order to cover the gap and contribute to the body of knowledge in the field of the literature. Based on the proposed framework, this paper invites researchers to empirically test the suggested propositions in order to further strengthen and develop understanding about individual and organizational factors as predictors of expatriate adjustment and job performance.
\end{abstract}

Keywords: Expatriate adjustment, Expatriate job performance, Direct/Indirect Support, Individual factors

\section{Introduction}

Global business expansions have shifted domestic human resource practices to global human resource practices thereby bring many new challenges for HR professionals and researchers. Therefore, expatriate adjustment and job performance is one of the major challenges among global human resource practices. MNC's have appointed many expatriates for their overseas operations in order to successfully achieve their global business objectives. MNC's have realized the importance of expatriates for their overseas operations and have invested more resources and effort to improve their 
performance, realizing that their overseas business operations are based on better expatriate performance. In other words, better performance of expatriates has become important to the success of multinationals organizations (Selmar: 2006). Researchers have been focusing on expatriate performance and adjustment (Paik et al., 2007; Mezias and Scandura, 2005) to help MNC's perform better in the international market. Templer (2010) argued that due to global business expansion and competition, there is a need to better understand the performance of international assignees. Therefore, MNC has allocated more resources and attention to manage expatriates performance and researchers have also been investigating those factors that affect such performance. Researchers have highlighted many factors that influence expatriate adjustment and job performance that are normally classified as individual factors, organizational level factors, and social level factors. Some researchers have tried to explain the role of individual factors in expatriate success (Caliguir, 2000; Ones \& Viswesvaran, 1997; Arthur \& Bennett, 1995; Black, 1990) but there are few studies that have examined the effects of individual factors on expatriate adjustment and job performance. Arthur \& Bennett (1995) suggested that researchers should fill this gap by determining whether individual and organizational factors predict expatriate success. Therefore, the purpose of this study is to highlight those individual and organizational factors which are unclear and/or have been ignored by past researchers in the expatriate literature.

\section{Self-Efficacy}

The concept of self-efficacy explains how individuals' perceptions about their ability to achieve certain tasks motivate them to achieve their objectives at the work place and in personal life. The concept of self-efficacy has widely been used in domestic employee performance and might be similarly applicable in the context of expatriate performance. Claus et al, (2011) argue that individuals having low self-efficacy leads to poor performance, absenteeism and high intention to search for the other job, whereas individuals having high self-efficacy leads to better performance and high organizational commitment. Only a few studies have examined the effects of self-efficacy on job performance at the domestic level but none of them have examined this relationship for expatriates or international assignees (Claus et al., 2011). Expatriates with high self-efficacy level may take initiative to solve problems and handle critical situations during international assignments, which may help them adjust to be host country's cultural practices and improve their performance. In addition, Bandura (1997) explained that individuals high on self-efficacy tend to be more proactive on initiating tasks, and make consistent efforts to achieve tasks and are persistent with problems and in the face of failure. Osman-Gani \& RockstuhI (2008) argue that self-efficacy influences job performance through social networking. Stajkovic and Luthans (1998) found that self-efficacy enhances job performance up to $28 \%$.

\section{Cultural Sensitivity}

Chen \& Starostam, (2000) defined cultural sensitivity as "an individual ability to develop a positive emotion towards understanding and appreciating cultural differences that promotes appropriate and effective behaviour in intercultural communication”. Expatriates ability to positively perceive the cultural differences might help them to adjust in the host country and improve their performance. Furthmore, the positive perception of an expatriate about cultural differences might help him/her to build better relationship and understanding with host county nationals which further improve job performance. In this regard, Shin et al., (2007) and Adler (1997) suggested that expatriates need to adjust their behaviour in the new culture in order to reduce stress and job uncertainty. Mol et al., (2005) highlighted that cultural sensitivity is an important personal characteristic for better expatriate job performance, and found that cultural sensitivity was strongly and positively related with job performance. In addition, cultural understanding and appreciation ability might help expatriates solve 
critical cultural issues. Claus et al., (2011) stated that expatriate cultural sensitivity helped them to deal with the complexity of cross culture and develop a global mind-set. Furthermore, Javidan et al., (2010) proposed that a global mind-set explains three major components which are defined by three specific attributes (intellectual capital, psychological capital and social capital).

\section{Previous International Experience}

Previous experience helps individuals learn from past mistakes and improves future life. Individuals can improve their life by learning from past mistakes but at the same time, past experience may guide an individual in performing different tasks and handling different critical situations. Learning from past mistakes and practicing certain sets of activities to achieve certain goals may help an individual improve their work and family life. More specifically, past experience might help an individual improve his/her job performance? In this regard, Claus et al, (2011) argue that previous job experience helps the individual develop traits knowledge which is vital for job performance and an important element in the domestic selection process. Past studies have highlighted this factor at the international level and found that previous international experience is positively related to expatriate job performance (Wang, 2001; Grosch, 2004; Tucker et al., 2004). In contrast, Mol et al., (2005) found that previous international experience did not influence expatriate job performance. The reason behind these findings may be due to moderating effects of expatriate adjustment as claimed by Mol et al, (2005), whereas the expatriate literature suggests that expatriate adjustment plays a mediating role between individual factors and expatriates job performance (Ramalu et al., 2011; Deller, 1997). Furthermore, some researchers have found positive effect of previous international experience on expatriate job performance (Black, 1988; Shaffer et al., 1999) but other researchers have not constantly supported these findings (Balck and Gregersen, 1991; Selmer, 2006). In addition, Selmer (1991) further proposed that previous international experience might play a moderating effect between adjustment and current assignment tenure. Therefore, conflicting results in past studies motivated the authors to further examine the role of previous international experience in expatriate job performance.

\section{Social Network}

Social networking refers to social relationships that link an individual or group with another individual or group (Hwang, 1998). Wasserman and Faust (1994) defined social networks as "a group of behaviours linked by one or more relationship types”. Wang and Rabindra (2004) explained that expatriate social networks consist of relationships between expatriates and host country nationals and friends. Johnson et al., (2002) suggested that when expatriates get information about jobs and the way of life from their social network, they adjust themselves in a foreign culture faster. Li and Rothstein (2009) argue that social networks play an important role in expatriate social life and career development. Kilduff and Krackhardt (1994) explain that better relationships with well-known persons in an organization bring about a boost in expatriate performance reputation. Silbert et al, (2001) found that social networking enhances expatriate career success through accessing information, resources, and career sponsorship. Osman-Gani amd RockstuhI (2008) argued that social networks play an important role in expatriate adjustment and job performance. Researchers have highlighted the concept of social network and explain that this help expatriate gain social support from host and home country nationals, and this support helps them to adjust in the host country and improve their job performance (Harrison et al., 2005; Wang \& Nayir, 2006; Liu \& Shaffer, 2005). Claus et al, (2011) argued that social networks support expatriates' intercultural adjustment and job performance. Osman-Gani amd RockstuhI (2008) argued that past studies have failed to explain the role of social support in expatriate adjustment and job performance due to conflicting results. 


\section{Direct and Indirect Support}

Erbacher et al., (2006) defined organizational support as referring to "the extent to which the organization including parent and local company provides assistance to expatriates”. Such expatriate assistance includes financial assistance, family support (locating schooling for kids, housing) and general assistance (mentoring and counselling). Kraimer and Wayne (2001) argue that career support is part of organizational support. Toh and Denisi (2005) explain organizational support for expatriates in terms of informational support, cooperation and emotional support and proposed that these three kinds of support facilitate expatriate adjustment. They further argue that informational support helps expatriates understand the host country culture whereas cooperation facilitates work adjustment. In addition, emotional support facilitates interaction adjustment and reduces the level of stress for expatriates (Toh and Denisi, 2005). Furthermore, Andreason (2003) highlighted that organization support can be divided into direct and indirect support. Direct support in the form of organization sponsored programs and indirect support in the form of organization encouraged activities and techniques. Caligirui et al., (1999) argue that researchers should highlight the positive effects of organizational support on expatriates' adjustment. Furthermore, Andreason (2003) pointed out that past research has ignored the topic of direct and indirect support and its influence on expatriate adjustment. Dowling et al., (1999) argued that MNC's provide tangible support to their international assignees in the form of compensation and benefits, but this support is not enough to adjust to life abroad. They further explain that the process of expatriate adjustment involves a whole range of emotional and psychological comforts. In this regard, Kaimer et al, (2001) suggested that "organization should provide language training and social opportunities for expatriates to interact with foreign nationals". Furthermore, pre-departure and cross cultural training, and good compensation packages might facilitate three dimensions of adjustment (Kaimer et al., 2003). In addition, Kaimer et al, (2003) found that perceived organizational support not only influenced expatriate interaction and general adjustment but also affected expatriate job performance.

\section{Expatriates Adjustment}

Past researchers have different views about adjustment and they have defined adjustment in terms of subjective well-being (Campbell, 1981) or unhappy feelings of expatriates about their circumstances (Munton and West, 1995). Furthermore, Selmer (1999) defined adjustment in terms of socio-cultural characteristics in achieving effectiveness in interpersonal exchange with host country nationals. Black (1988) defined adjustment as mostly "acceptance”, which explains that adjustment refers to psychological discomfort which can be categorized as work, general, and interaction adjustment.

Work adjustment refers to expatriate comfort with the job; general adjustment refers to expatriate comfort with non-work factors like food, language, transportation, entertainment etc; and interaction adjustment refers to comfort associated with interaction of expatriates with host country nationals inside and outside the workplace (Black, 1988). Black and Stephens (1989) have operationalized the three dimensions of adjustment and Shaffer et al, (1999) validated these three dimensions. Past researchers had highlighted the concept of expatriate adjustment and had explained that expatriate adjustment is a multi-dimensional contract (work, general and interaction) (Bhaskar et al., 2005, Harrison et al., 2005). Cultural adjustment is related to a vocational activities and work adjustment is related to work, whereas interaction adjustment is related to both work and non-work environments (Shaffer et al., 1999). Kraimer et al, (2003) found that expatriate adjustment is positively related to job performance and when expatriates properly adjust to the host country general environment, their job performance will be similar to such performance in the home country (Lee and Sukoco; 2010). In addition, if expatriates develop better relationships with local employees, this will be helpful for expatriates to meet the performance expectations of the company ((Lee and Sukoco, 2010). Furthermore, Mol et al., (2005) pointed out that cross-cultural adjustment is positively related to 
expatriate job performance. Some researchers have empirically examined all expatriate adjustment dimensions (Thomas \& Lazarova, 2006; Lazarova et al., 2010), but the majority of researchers have focused on work and interaction dimensions only (Caligirui, 1997; Takeuchi et al., 2005).

Florkowski and Fogel (1999) pointed out that even though many researchers have highlighted the role of expatriate adjustment in expatriate success, the expatriate adjustment role is still unclear. In addition, Maruyama (1992) argued that if expatriates fail to adjust themselves in the host country, their level of cultural insensitivity, indifference and ignorance increase. Furthermore, Templer et al., (2006) suggested that expatriate adjustment is a key indicator for expatriate success in their international assignment. Claus et al., (2011) highlighted that past research focused on job performance in expatriate contexts, but most researchers ignored expatriate adjustment in their studies (Tucker et al., 2004; Liu \& Schaffer, 2005; Shay \& Baack, 2006; Osman-gani \& Rockstuhl, 2008). In addition, Tucker et al, (2004) argued that the relationship between inter cultural adjustment and expatriate job performance is complex and not well understood. Claus et al, (2011) argued that even though expatriate adjustment and job performance are linked to each other logically, empirical research still lacks empirical evidence. Shaffer et al, (2006) highlighted that few past studies have examined the effects of the big five and individual factors on expatriate performance, but they have ignored the role of expatriate adjustment in terms of work, general, and interaction adjustment.

\section{Job Performance}

Harrison and Shaffer (2005) argued that job performance is a function of the amount of time and energy (effort) that an expatriate devotes to his/her job. Theory of job performance explains that job performance is a multidimensional construct which consists of task dimension and contextual dimension. Researchers have highlighted many factors that influence expatriate job performance such as goal orientation, self-efficacy, self-monitoring, task, and people orientation, relationship ability, and international experience (Shaffer et al., 2006; Wang \& Takeuchi, 2007). Caligiuri (1997) argued that early return of expatriates influences their job performance. This study will only focus on personality traits and investigate the influence of personality traits on expatriate adjustment and job performance. In order to measure expatriate job performance, researchers have used different sources like peers, supervisors, subordinates etc., which can be host country nationals or the third country nationals. Paik et al, (2007) argued that performance of expatriates heavily depends on the host country workforce, and researchers have neglected this area. Jassawalla et al, (2004) argued that expatriate adjustment mostly depends on how cross-cultural conflicts with the host country workforce are dealt with. They further argue that expatriates who successfully handle their conflicts with the host country workforce are more likely to experience smooth adjustment at their workplace. Templer (2010) highlighted that global business expansion requires more expatriates for international assignments which forces HRD professionals to effectively manage and better understand expatriate performance.

In order to cover the gap in the expatriate literature (as discussed in the above sections), this study developed conceptual framework (Figure 1) and proposed the following propositions:

Proposition 1: Expatriate adjustment (general, work and interaction) mediate the relationship between direct \& indirect support and job performance (peer- and supervisor-rated).

Proposition 2: Expatriate adjustment (general, work and interaction) mediate the relationship between self-efficacy and expatriate job performance (peer- and supervisor-rated). 
Proposition 3: Expatriate adjustment (general, work and interaction) mediate the relationship between cultural sensitivity and expatriates job performance (peer- and supervisor-rated).

Proposition 4: Expatriate adjustment (general, work and interaction) mediate the relationship between previous international experience and expatriates job performance (peer- and supervisor-rated).

Proposition 5: Expatriate adjustment (general, work and interaction) mediate the relationship between social networking and expatriate job performance (peer- and supervisor-rated).

Individual Factors

Performance
Cross Cultural Adjustment

Job

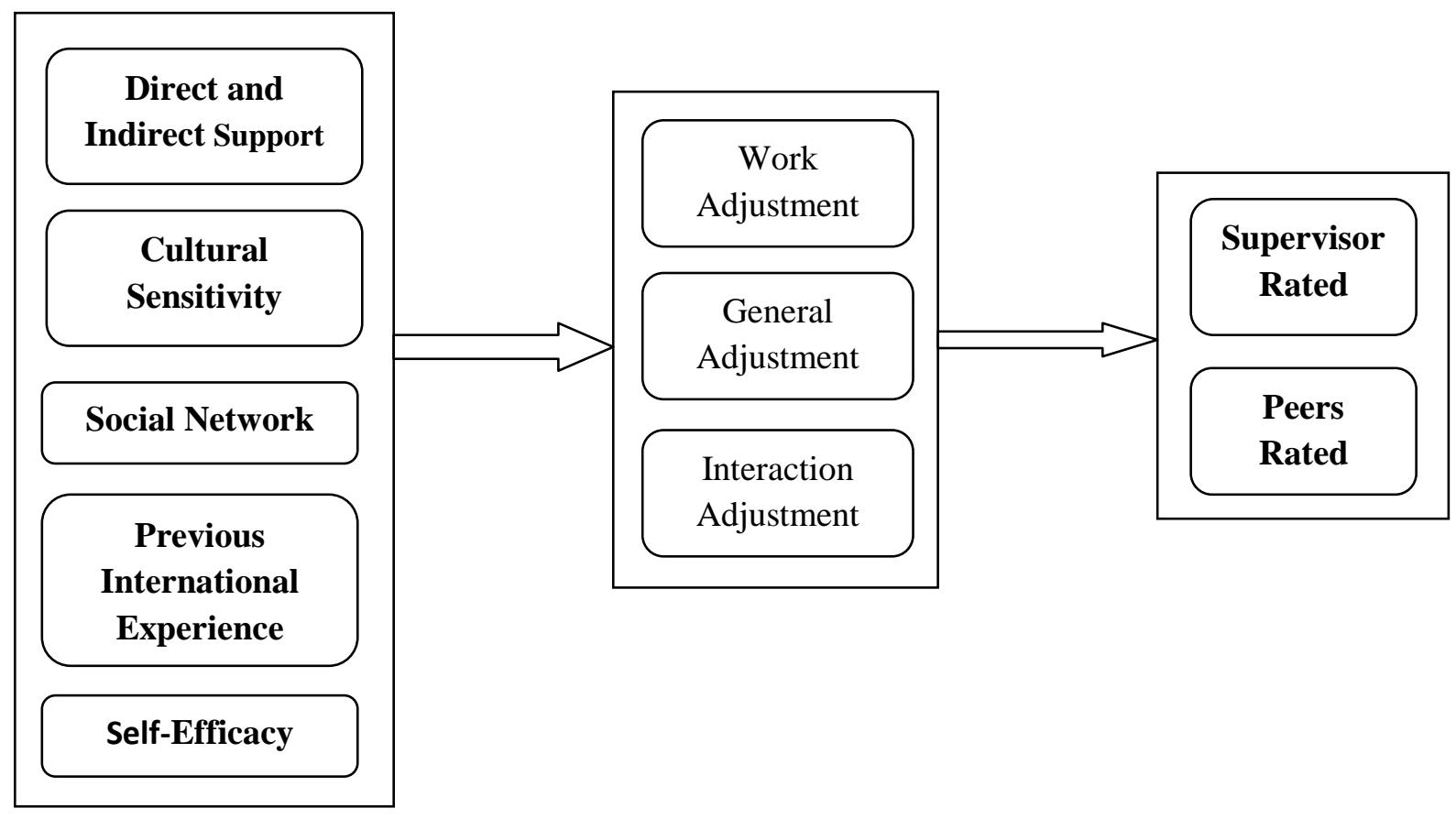

Figure 1. Conceptual Framework

\section{Conclusion and Future Research Directions}

Global business expansion has increased the demand for employees for international assignment and MNC's have been investing maximum resources and effort to manage their international assignees performance. Ramalu, Wei, and Rose (2011) argued that organizations receive multiple advantages while having a diverse workforce and expatriates. A survey conducted by (Windham International, 1999) on human resource managers and international relocation experts reported that organizations continue to rely on expatriates and 41 present of corporate revenues comes from outside the home country. Beechler and Woodward (2009) argued that organizations need expatriate employees in order to internationalize markets and competition. Therefore, developing economies adopt international strategies for a global expansion and recruit more expatriates for successful and smooth process of global expansion. Parallel to HR practitioners, researchers have also been trying to 
investigate the predictors of expatriate adjustment, and job performance, but unfortunately some of the individual and organizational factors as predictors to expatriate adjustment and job performance have been ignored by past researchers. Even though some researchers have attempted to conceptualize the relationship between individual factors, past studies still lack clear direction for such relationships (Cheng \& Lin, 2009; Mol et al., 2009). In this regard, Andreason (2003) pointed out that past research has ignored the topic of direct and indirect support and its influence on expatriate adjustment. Therefore, this study attempts to provide theoretical support for individual and organizational factors as predictors for expatriate adjustment and job performance and propose that expatriate adjustment (work, general and interaction) mediates the relationship between individual factors (self-efficacy, previous international experience and social network), organizational support (direct and indirect support) and job performance ( as rated by peers and supervisor). This study has also developed propositions and proposes that future researchers should empirically test this proposed model in order to provide empirical support.

Researchers have examined the 360-degree performance feedback at the domestic level, but this area has been ignored in expatriate assignment. Past researchers have examined expatriate performance through supervisors, but this study proposed that researchers should examine expatriate performance through both supervisor and host country nationals and peers which includes third country nationals. As a part of the 360-degree performance feedback, supervisor and peers may provide clear insights about expatriate performance. Sinangirl and Ones (2001) pointed out that the area of expatriate management from the host country national's point of view has been ignored. Bhatti et al. (2012) highlighted the importance and role of host country nationals in expatriate performance and suggested that host country national feedback about expatriate performance is vital. Therefore, future studies should test the proposed model and evaluate expatriate performance through host country nationals or peers in order to better understand expatriate performance. Furthermore, empirical examination of the proposed model in multiple settings might further contribute to the body of knowledge in expatriate literature.

This conceptual paper will help the researchers and managers to better understand the role of individual and organizational factors in expatriates adjustment and performance during international assignment. From theoretical perspectives, researchers need to test this frame work in order to further explain the importance of individual and organizational factors in expatriate literature. Limited literature on expatriate adjustment and job performance is one of the major reasons of poor performance of employees during international assignment. Therefore, it is researcher's responsibility to throw light on expatriate adjustment and job performance and well explain the role of individual and organizational factors in expatriate literature. Furthermore, this paper is also effective reading for managers and professionals dealing with the expatriate performance and adjustment. Human resource professionals and top management of the organizations should provide direct and indirect support to the expatriates and enable them to adjust in the host country environment. The expatriate performance in the host country will be better if expatriate adjustment in terms of work, interaction and general adjustment in the host country environment.

This paper also explains the importance of cultural sensitivity in expatriate adjustment and job performance and suggested that managers and top management should pay attention on the cultural sensitivity of the employees at the time of recruitment. Training to overcome cultural sensitivity is one of the best remedy for expatriate adjustment in host country environment. Similar like cultural sensitivity, previous international experience also important factor for expatriate adjustment and job performance and human resource professionals should consider this factor before selecting employee for international assignment. In addition, managers should not under estimate the importance of social network and self-efficacy while selecting employee for international assignment. Employees with ability to expand their social network and strong self-efficacy can adjust in the host country environment faster than others. With reference to expatriate's performance management, the manager 
should implement 360 degree performance appraisal system. The human resource managers should appraise expatriate performance by using peer and supervisor feedback to better understand the performance level of the employees in host country.

\section{References}

[1] Adler, N. J. (1997). International Dimensions of Organizational Behaviour. Cincinnati. Ohio: South-Western College Publishing.

[2] Andreason, W. A. (2003). Direct and Indirect forms of in-country support for expatriates and their families as a means of reducing premature returns and improving job performance. International Journal of Management, 20(4), 548-555.

[3] Arthur, W., \& Bennett, W. (1995). The international assignee: The relative importance of factors perceived to contribute to success. Personnel Psychology, 48, 99-114.

[4] Bandura, A. (1997). Self-efficacy: The exercise of control. New York: Freeman.

[5] Beechler, S., \& Woodward, I. C. (2009), The global war for talent. Journal of International Management, 15(3), 273-285.

[6] Bhaskar-Shrinivas, P., Harrison, D. A., Shaffer, M. A., Shaffer, M. A., \& Luk, D. M. (2005). Input base and time-based models of international adjustment: Meta analytic evidence and theoretical extensions. Academy of Management Journal, 48, 257-281.

[7] Bhatti, M. A., Sundram, V. P. K., \& Hoe, C. H. (2012). Gender Stereotypes: Expatriates Job Performance and Gender Perception through Host Country Nationals (HCN's) Perspectives, International Journal of Business and Management, 7(17), 27-33. http://dx.doi.org/10.5539/ijbm.v7n17p27

[8] Black, J. S. (1988). Work Role Transitions: A study of American Expatriates In Japan. Journal of International Business Studies, 19, 277-94.

[9] Black, J. S. (1990). Locus of Control, Scocial Support, Stress and Adjustment in international Transfers. Asia Pacific Journal of Management, 7(1), 1-29.

[10] Black, J. S., \& Gregersen, H. B. (1991). Antecedents of Cross-cultural Adjustment for expatriates in Pacific Rim Assignment. Human Relation, 44, 497-515.

[11] Black, J. S., \& Stephens, G. K. (1989). The influence of the Spouse on American Expatriate Adjustment and Intent to stay in Pacific Rim Overseas assignments. Journal of management, 15(4), 529-44.

[12] Caligiuri, P. M. (1997). Assessing expatriate success: Beyond just being there. In Z. Aycan (ed.), new approaches to employee management expatriates management: theory and research (Vol. 4, pp. 117-40). Greenwich, CT: JAI press.

[13] Caligiuri, P. M. (2000). The big five personality characteristics as predictors of expatriates desire to terminate the assignment and supervisor-rated performance. Journal of Personal Psychology, 53, 67-87.

[14] Caligiuri, P. M., Joshi, A., \& Lazarove, M. (1999). Factors influencing the adjustment of women on global assignments. International Journal of Human Resource Management, 10, 163-179.

[15] Campbell, A. (1981). The sense of wellbeing in America. New York, McGraw hill.

[16] Chen, G. M., \& Starosta, W. J. (2000). The development and validation of the intercultural sensitivity scale. Human Communication, 3, 1-15. 
[17] Cheng, H. L., \& Lin, C. Y. Y. (2009). Do as the large enterprises do?: Expatriate selection and overseas performance in emerging markets: The case of Taiwan SMEs. International Business review, 18, 60-75. http://dx.doi.org/10.1016/j.ibusrev.2008.12.002.

[18] Claus, L., Lungu, P. A., \& Bhattacharjee, S. (2011). The effects of individual, organizational and societal variables on the job performance of expatriate managers. International Journal of Management, 28(1:2), 249-271.

[19] Deller, J. (1997). Expatriates selection: Possibilities and limitation of using personality scales. In Z. Aycan (Ed.), New approaches to employee management: Expatriate management, theory and research (Vol. 4, pp.93-116). Stamford CT: JAI press.

[20] Dowling, P. J., Welch, D. W., \& Schuler, R. S. (1999). International Human Resource Management ( $3^{\text {rd }}$ Edition). Cincinnati: International Thompson Publishing.

[21] Erbacher, D., Netto, B. D., \& Espana, J. (2006). Expatriate success in China: Impact of personal and situational factors. The Journal of American Academy of Business, Cambridge, 9(2), 183-188.

[22] Florkowski, G. W., \& Fogel, D. S. (1999). Expatriate adjusment and commitment: the role of host unit treatment. International Journal of Human Resource Management, 10(5), 783-807.

[23] Grosch, M. (2004). Validation of Biodata Inventory for expatriate selection: Assessing Cross cultural adaptability. Unpublished doctoral disseratation, Auburn University, Auburn, Alabama.

[24] Harrison, D. A., \& Shaffer, M. A. (2005). Mapping the criterion space for expatriate success: task and relationship based performance, effort and adaptation. The international journal of human resource management, 18(8), 1454-1474.

[25] Hwang, K. K. (1998). Favor and face: Chinese Power game. Taipei: Chu Liu Publisher.

[26] Jassawalla, A., Truglia, C., \& Garvey, J. (2004). Cross cultural conflict and expatriates manager adjustment: an exploratory study. Management Decision, 42(7), 837-49.

[27] Javidan, M., Teagarden, M., \& Bowen, D. (2010). Making it overseas. Hrvard Business Review (pp. 109-113).

[28] Johnson, K. P., Williams, B. L., Drown, D. M., Adams, R. J., \& Clayton, D. H. (2002). The population genetics of host specificity: Genetic differentiation in dove lice (Insecta: Phthiraptera). Molecular Ecology, 11, 25-38.

[29] Kilduff, J., \& Krackhardt, D. (1994). Bringing the individual back in: A structural analysis of the internal market for reputation in orgainzation. Academy of Management Journal, 37(1), 87-108.

[30] Kraimer, M. L., Wayne, S. J., \& Jaworski, R. A. (2001). Source of support and expatriates performance: The mediating role of expatriate adjustment. Personal psychology, 54, 71-99.

[31] Lazarova, M., Westman, M., \& Shaffer, M. A. (2010). Elucidating the positive side of the work family interface on international assignments: A model of expatriate work and family performance. Academy of Management Journal, 35(1), 93-117.

[32] Lee, L. Y., \& Sukoco, M. B. (2010). The effects of cultural intelligence on expatriate performance: the moderating effects of international experience. The international journal of human resource management, 21(7), 963-981.

[33] Liu, Z., \& Shaffer, M. A. (2005). An investigation of expatriate adjustment and performance: a social captial perspective. International journal of cross-cultural management, 5(3), 235-254.

[34] Maruyama, M. (1992). Lessons from Japanese Management Failures in Foreign Countries. Human system management, 11, 41-48. 
[35] Mezias, J. M., \& Scandura, T. A. (2005). A needs-driven approach to expatriate adjustment and career development: a multiple mentoring perspective. Journal of International Business Studies, 36, 519-538.

[36] Mol, S. T., Born, M. P., Willemsen, M. E., \& Molen, H. T. V. D. (2005). Predicting expatriate job performance for selection purposes: A quantitative review. Journal of cross cultural psychology, 36(5), 339-353.

[37] Mol, S. T., Born, M. P., Willemsen, M. E., Molen, H. T. V. D., \& Derous E. (2009). When selection ratios are high: Predicting the expatriation willingness of prospective domestic entry-level job applicants. Human Performance, 22(1), 1-22.

[38] Munton, A. G., \& West, M. A. (1995). Innovation and personal change: Patterns of adjustment to relocation. Journal of organizational behavior, 16(4), 363-376.

[39] Ones, D. S., \& Viswesvaran, C. (1997). Personality determinants in the prediction of aspects of expatriates job success. In Ayean Z (Ed.), expatriates management, Theory and practice (pp. 63-92). Greenwich CT JAI press.

[40] Osman-Gani, A. M., \& RockstuhI, T. (2008). Antecedents and consequences of social network characteristics for expatriate adjustment and performance in overseas assignments: Implications for HRD. Human resource development review, 7, 32-57.

[41] Paik, Y., Parboteeah, P. K., \& Shim, W. (2007). The relationship between perceived compensation, organizational commitment and job satisfaction: the case of Mexican workers in the Korean Maquiladoras. International Journal of Human Resource Management, 18(10), 1768-1781.

[42] Ramalu, S., Wei, C., \& Rose, C. R. (2011). The effects of cultural intelligence on cross cultural adjustment and job performance amongst expatriates in Malaysia. International Journal of Business and Social Science, 2(9), 59-71.

[43] Seibert, S. E., Kraimer, M. L., \& Liden, R. C. (2001). A social capital theory of career success. Academy of Management Journal, 44(2). 219-237.

[44] Selmer, J. (1999). Effects of coping strategies on sociocultural and psychological adjustment of western expatriate managers in the PRC. Journal of World Business, 34(1), 41-51.

[45] Selmer, J. (2006). Adjustment of Business Expatriates in Greater China: A Strategic Perspective. International Journal of Human Resource Management, 17(12), 1994-2008.

[46] Shaffer, M. A., Harrison, D. A., \& Gilley, K. M. (1999). Dimensions, Determinants and differences in the expatriate adjustment process. Journal of International Business Studies, 30, 557-581.

[47] Shaffer, M. A., Harrison, D. A., Gregersen, H., Black, J. S., \& Ferzandi, L. A. (2006). You can take it with you: Individual differences and expatriate effectiveness. Journal of Applied Psychology, 91(1), 109-125.

[48] Shay, J., \& Baack, S. (2006). An empirical investigation of the relationships between modes and degree of expatriate adjustment and multiple measures of performance. International Journal of Cross Cultural Management, 6(3), 275-294.

[49] Shin, S. J., Morgeson, F. F., \& Campion, M. A. (2007). What you do depends on where you are: Understanding how domestic and expatriate work requirements depend upon cultural context. Journal of International Business Studies, 38, 64-83.

[50] Sinangil, H. K., \& Ones, D. S. (2001). Expatriate Management. In N. Anderson, D. S. Ones, H. Sinangil, \& C. Viswesvaran (Eds.). Hand book of industrial work and organizational psychology (1, 424-443). London, Sage. 
[51] Stajkovic, A. D., \& Luthans, F. (1988). Self-efficacy and work-related performance: A meta-analysis. Psychological Bulletin, 124(2), 240-261.

[52] Takeuchi, R., Tesluk, P. E., Yun, S., \& Lepak, D. P. (2005). An integrative view of international experience. Academy of Management Journal, 48, 85-100.

[53] Templer, K. J. (2010). Personal attributes of expatriate managers, subordinate ethnocentrism, and expatriate success: a host country perspective. The International Journal of Human Resource Management, 21(10), 1754-1768.

[54] Thomas, D. C., \& Lazarova, M. B. (2006). Expatriate adjustment and performance: A critical review, In G. Stahl \& I. Bjokman (Eds.), Handbook of research in international human resource management (pp.247-264). Northampton, MA: Eldward Elgar.

[55] Toh, S. M., \& Denisi, S. A. (2005). A local perspective to expatriate success. Academy of management executives, 19(1), 132-146.

[56] Tucker, M. F., Bonial, R., \& Lahti, K. (2004). The definition, measurement and prediction of intercultural adjustment and job performance among corporate expatriates. International journal of intercultural relations, 28, 221-251.

[57] Wang, X. (2001). Expatriate social support network, psychological well-being and performance: A theoretical examination and an empirical test. Unpublished doctoral dissertation, McGfill University, Montreal, Canada.

[58] Wang, X., \& Nayir, Z. (2006). How and when is social networking important? Theoretical examination and a conceptual model. International journal of cross-cultural management, 2, 321-337.

[59] Wang, X., \& Rabindra, N. K. (2004). Nationality, social network and psychological well-being. International Journal of Human Resource Management, 15(4-5), 775-793.

[60] Wasserman, S., \& Faust, K. (1994). Social network analysis: Methods and Application. Cambridge, MA: Cambridge University Press.

[61] Windham International and National Foreign Trade Council, Inc. (1998). Global relocation trends: 1998 survey report. New York: WI. 